\title{
The Effect of Arbuscular Mycorrhizae Fungi (AMF) Glomus sp. and Compost on Growth and Yield of Maize (Zea mays $L$.)
}

\author{
Susi Mindarti ${ }^{1}$, Karuniawan P. Wicaksono ${ }^{2}$, Titin Sumarni ${ }^{2}$ \\ ${ }^{I}$ (Master Program of Plant Science, Faculty of Agriculture, University of Brawijaya, Malang-Indonesia) \\ ${ }^{2}$ (Faculty of Agriculture, University of Brawijaya, Malang-Indonesia)
}

\begin{abstract}
Objectives of the research were to study the effect of Arbuscular Mycorrhizae Fungi could reduce the need of compost and increase the yield of maize. The research applied Split Plot Design by 3 replications. The main plot was AMF, which comprised of 2 levels: without AMF and AMF. Sub Plot was dosage of the compost, which comprised of 5 levels, such as: 0, 5, 10, 15 and 20 ton ha ${ }^{-1}$. Result of the research showed significant interaction between AMF and compost on various observed parameters. On parameter of growth, AMF treatment and dosage of the compost 10 ton ha $a^{-1}$ have been able to increase leaf area, dry weight of root, dry weight of shoot and dry weight of cob, as well as reduce the need of compost for about $50 \%$. On parameter of yield, AMF treatment and compost 15 ton ha $a^{-1}$ have been able to increase the weight of cob and weight of 100 seeds, as well as to reduce the need of compost for about $25 \%$, while on weight of dry grains, the increasing dosage of compost up to 20 ton $\mathrm{ha}^{-1}$ has still been able to increase the yield. The application of AMF by dosage of compost 10 and 15 ton $\mathrm{ha}^{-1}$ as better as in increasing weight of the corn grains.
\end{abstract}

Keywords: Arbuscular Mycorrhizae Fungi (AMF), compost fertilizer, maize (Zea mays L.)

\section{Introduction}

Maize belongs to cereal crops, which is valuable as foodstuff, feed and biofuel. In Indonesia, the national production of maize in 2013 decreased $4.5 \%$ from 19.39 million ton in 2012 became 18.51 million ton (Ministry of Agriculture, 2014) [1]. Maize productivity decrease due to various problems in breeding, which frequently occur and one of them is nutrient availability in the soil. In general, the soil problem in tropical area relates to low level of organic materials content in the soil (Handayanto and Hairiah, 2007) [2].

Adding the organic fertilizer, which is derived from animal manure, does not only add the organic materials in the soil, but also contribute to nutrient availability, such as N, P, and K, as well as make the application of inorganic fertilizer become more efficient. In agricultural practices, full organic fertilization is highly difficult to be applied due to relative lesser amount of nutrient that contain in the organic material (Atmojo, 2010) [3]. Application of greater amount of organic fertilizers in the same time is difficult; therefore it requires an effort to reduce the organic fertilizer. Other effort that can be done to overcome condition of the soil as medium of the crop is the application of microbial-based technology. Arbuscular Mycorrhizae is an alternative that can be applied to increase the fertilization efficiency (Mosse, 1981) [4]. The role of AMF on roots would be able to increase ability of the root in absorbing P, efficient fertilization, assisting the growth and viability of the crop (Blal et al., 1997)[5].

\section{Material And Method}

The research was conducted at Dadaptulis Village - Junrejo, Batu - East Java, at the altitude of $560 \mathrm{~m}$ above sea level (asl) in Inceptisol soil, and temperature ranges $26^{\circ}-29^{\circ} \mathrm{C}$. The research was started from September to December 2013. Materials of the research included: corn seed of BISI-18 variety, Arbuscular Mycorrhizae Fungi Glomus sp. using zeolite medium, cow manure, inorganic fertilizers of Urea, SP-36 and $\mathrm{KCl}$. The research applied Split Plot Design by 3 replications, such as Main Plot: Arbuscular Mycorrhizae Fungi (M) that comprised of 2 levels, such as M0: without AMF and M1: AMF. Sub Plot: Compost (K) comprised of 5 levels, such as K0: 0 ton ha ${ }^{-1}, \mathrm{~K} 1: 5$ ton ha ${ }^{-1}, \mathrm{~K} 2: 10$ ton ha ${ }^{-1}, \mathrm{~K} 3: 15$ ton ha ${ }^{-1}$ and K4: 20 ton ha $\mathrm{h}^{-1}$. The application of AMF simultaneously with the seed planting for about $30 \mathrm{~g} \mathrm{plant}^{-1}$ and application of compost fertilizer was given a week before planting. Urea fertilization was applied by dosage of $350 \mathrm{~kg} \mathrm{ha}^{-1}$, SP 36 by dosage of $300 \mathrm{~kg} \mathrm{ha}^{-1}$ and $\mathrm{KCl}$ by dosage of $100 \mathrm{~kg} \mathrm{ha}^{-1}$. Observation on growth included: leaf area $\left(\mathrm{cm}^{2}\right)$, dry weight of root $(\mathrm{g})$, dry weight of shoot $(\mathrm{g})$ and dry weight of cob $(\mathrm{g})$. Observation on harvest included: weight of $\mathrm{cob}(\mathrm{g})$, weight 100 seeds $(\mathrm{g})$ and weight of grains $\left(\right.$ ton $\left.\mathrm{ha}^{-1}\right)$. Chemical analysis on soil has been done before planting as presented in Table 1. Data of the observation was analyzed by analysis of variance (F-test) at the level $5 \%$ in order to find out the effect of treatment. If the result has non significant difference, it would be followed by LSD (Least Significant Difference) test by significant level of 5\% to find out any difference among treatments. 
Table 1. Chemical analysis on soil at Dadaptulis Village, Junrejo-Batu

\begin{tabular}{lcl}
\hline \multicolumn{1}{c}{ Parameter } & Value & Status \\
\hline & & \\
$\mathrm{pH} \mathrm{H} \mathrm{H}_{2} \mathrm{O}$ & 7.33 & Medium \\
$\mathrm{C}$-organic $(\%)$ & 0.90 & Low \\
$\mathrm{N}(\%)$ & 0.078 & Very low \\
$\mathrm{Ratio} \mathrm{C/N}$ & 11.54 & Medium \\
$\mathrm{P}_{2} \mathrm{O}_{5} \mathrm{O}$ (sen $(\mathrm{ppm})$ & 9.97 & Low \\
$\mathrm{K}(\mathrm{me})$ & 0.10 & Low \\
\hline
\end{tabular}

\section{Result And Discussion}

Result for analysis of variance showed significant interaction between AMF treatment and compost fertilizer on variable of leaf area, dry weight of root, dry weight of shoot and dry weight of cob at 70 DAP (days after planting) as presented in Table 2 below.

Table 2. Mean of leaf area $\left(\mathrm{cm}^{2}\right)$, dry weight of root $(\mathrm{g})$, dry weight of shoot $(\mathrm{g})$ and dry weight of cob (g) due to interaction between AMF treatment and compost fertilizer at 70 DAP

\begin{tabular}{ccccc}
\hline Treatment & Leaf area $(\mathrm{cm} 2)$ & Dry weight of root $(\mathrm{g})$ & Dry weight of shoot $(\mathrm{g})$ & Dry weight of cob $(\mathrm{g})$ \\
\hline M0K0 & $1242.32 \mathrm{a}$ & $5.76 \mathrm{a}$ & $20.15 \mathrm{a}$ & $4.87 \mathrm{a}$ \\
M0K1 & $1366.47 \mathrm{a}$ & $6.24 \mathrm{ab}$ & $21.87 \mathrm{a}$ & $5.68 \mathrm{ab}$ \\
M0K2 & $1464.31 \mathrm{ab}$ & $6.60 \mathrm{ab}$ & $22.16 \mathrm{ab}$ & $6.12 \mathrm{abc}$ \\
M0K3 & $1470.85 \mathrm{ab}$ & $7.23 \mathrm{ab}$ & $25.56 \mathrm{bc}$ & $7.41 \mathrm{abc}$ \\
M0K4 & $1720.55 \mathrm{bc}$ & $7.95 \mathrm{bc}$ & $28.15 \mathrm{c}$ & $7.40 \mathrm{c}$ \\
M1K0 & $1305.42 \mathrm{a}$ & $5.54 \mathrm{a}$ & $22.46 \mathrm{ab}$ & $4.98 \mathrm{a}$ \\
M1K1 & $1459.44 \mathrm{ab}$ & $7.63 \mathrm{~b}$ & $27.93 \mathrm{~cd}$ & $7.71 \mathrm{bc}$ \\
M1K2 & $1748.29 \mathrm{bc}$ & $30.27 \mathrm{de}$ & $8.53 \mathrm{~d}$ \\
M1K3 & $1953.94 \mathrm{c}$ & $31.70 \mathrm{de}$ & $9.10 \mathrm{~d}$ \\
M1K4 & $2002.84 \mathrm{c}$ & $9.23 \mathrm{c}$ & $32.33 \mathrm{e}$ & 1.67 \\
\hline LSD 5\% & 286.73 & $9.64 \mathrm{c}$ & 3.53 & \\
\hline
\end{tabular}

Notes : numbers followed by the same letter show non significant difference on LSD test of 5\%

\subsection{Leaf area}

AMF treatment by the application of compost fertilizer 10 ton $\mathrm{ha}^{-1}$ has been able to increase leaf area and the result has non significant difference with dosage of compost 20 ton/ha without AMF. AMF treatment by dosages of 10, 15 and 20 ton $\mathrm{ha}^{-1}$ have the same results and good in increasing leaf area. Therefore, the application of compost 10 ton $\mathrm{ha}^{-1}$ has been able to increase leaf area and reduce the need of compost for about $50 \%$.

\subsection{Dry weight of root}

AMF treatment by dosage of compost 10 ton $\mathrm{ha}^{-1}$ has been able to increase leaf area and the result has non significant difference with dosage of compost 20 ton $\mathrm{ha}^{-1}$ without AMF. For AMF treatment by dosages of 10,15 and 20 ton $\mathrm{ha}^{-1}$ have the same results and good in increasing dry weight root. This is similar to the leaf area, in which the application of compost 10 ton ha ${ }^{-1}$ has been able to increase dry weight of root and reduce the need of compost for about $50 \%$.

\subsection{Dry weight of shoot}

AMF treatment by dosage of compost 5 ton $\mathrm{ha}^{-1}$ has been able to increase dry weight of shoot in comparison with treatment without AMF, which requires dosage of 20 ton ha ${ }^{-1}$. AMF treatment by dosages of 10, 15 and 20 ton $\mathrm{ha}^{-1}$ have non significant results. The result was parallel with the research by Jan et al. (2014) [6] that applied 1/2 dosage (half compost) and 1 dosage of compost (full compost), and both of them were good in increasing growth and yield of wheat.

\subsection{Dry weight of cob}

AMF treatment by compost of 5 ton $\mathrm{ha}^{-1}$ has been able to increase dry weight of ear and the result has non significant difference with treatment without AMF by dosage of 20 ton $\mathrm{ha}^{-1}$. AMF treatment by dosages of compost 10, 15, and 20 ton $\mathrm{ha}^{-1}$ have not significantly different results in increasing dry weight of cob.

At 14 and 42 DAP, there was not interaction between AMF treatment and compost fertilizer on variables of leaf area, dry weight of root and dry weight of shoot as presented in Table 3 below. 
Table 3. Mean of leaf area (LA), dry weight of root (DWR) and dry weight of shoot (DWS) due to AMF treatment and compost treatment at 14 and 42 DAP

\begin{tabular}{|c|c|c|c|c|c|}
\hline \multirow{2}{*}{ Treatment } & \multicolumn{3}{|c|}{14 DAP } & \multicolumn{2}{|l|}{42 DAP } \\
\hline & LA & DWR & DWS & LA & DWR \\
\hline Without AMF & 214.94 & $0.19 \mathrm{a}$ & 0.91 & 621.11 & 1.38 \\
\hline AMF & 228.38 & $0.23 \mathrm{~b}$ & 1.01 & 651.57 & 1.89 \\
\hline LSD 5\% & ns & 0.02 & $\mathrm{~ns}$ & $\mathrm{~ns}$ & $\mathrm{~ns}$ \\
\hline \multicolumn{6}{|l|}{ Compost } \\
\hline 0 & $207.56 \mathrm{a}$ & $0.17 \mathrm{a}$ & $0.83 \mathrm{a}$ & $608.31 \mathrm{a}$ & $1.30 \mathrm{a}$ \\
\hline 5 & $211.33 \mathrm{a}$ & $0.18 \mathrm{~b}$ & $0.87 \mathrm{ab}$ & $622.50 \mathrm{~b}$ & $1.44 \mathrm{a}$ \\
\hline 10 & $215.99 \mathrm{a}$ & $0.21 \mathrm{~b}$ & $0.92 \mathrm{~b}$ & $637.21 \mathrm{c}$ & $1.65 \mathrm{~b}$ \\
\hline 15 & $228.33 \mathrm{~b}$ & $0.23 \mathrm{c}$ & $1.02 \mathrm{c}$ & $647.01 \mathrm{c}$ & $1.80 \mathrm{bc}$ \\
\hline 20 & $245.09 \mathrm{c}$ & $0.26 \mathrm{~d}$ & $1.16 \mathrm{~d}$ & $666.67 \mathrm{~d}$ & $1.98 \mathrm{c}$ \\
\hline LSD 5\% & 13.3 & 0.02 & 0.08 & 13.89 & 0.22 \\
\hline
\end{tabular}

Notes : numbers followed by the same letter show non significant difference on LSD test of 5\%

ns $=$ non significant difference

Table 3 shows that during initial growth at 14 DAP, treatment without AMF and AMF have non significant differences in increasing leaf area, as well as at 42 DAP. On variable of dry weight of root at 14 DAP, AMF treatment has shown significant difference in increasing the yield, but it has shown non significant difference at 42 DAP. Treatment using compost at 14 DAP by dosage of 20 ton ha ${ }^{-1}$ could increase the leaf area, while for dosages of 0,5 and 10 ton $\mathrm{ha}^{-1}$, the results have non significant differences. At 42 DAP, leaf area has increased by the application of 20 ton ha $^{-1}$ compost, but dosages of 10 and 15 ton ha ${ }^{-1}$ have better results. Dry weight of root has the highest yield by the application of 20 ton $\mathrm{ha}^{-1}$ compost, but at 42 DAP by dosages of 15 and 20 ton $\mathrm{ha}^{-1}$, they have the better results in increasing dry weight of root.

Variable for dry weight of shoot at 14 DAP has shown non significant different result, but at 42 DAP, an interaction has occurred among treatments. Table 4 below shows an interaction between AMF treatment and compost fertilizer at $42 \mathrm{DAP}$. On the treatment without AMF by the increasing dosage of compost 20 ton ha $^{-1}$, the result has non significant difference in increasing dry weight of shoot. On AMF treatment by dosages of compost 15 and 20 ton $\mathrm{ha}^{-1}$, the results have significant difference with the treatment without compost, but they have insignificant difference with dosages of 5 and 10 ton $\mathrm{ha}^{-1}$.

Table 4. Mean for dry weight of shoot $(\mathrm{g})$ due to interaction between AMF treatment and compost fertilizer at 42 DAP

\begin{tabular}{|c|c|c|c|c|c|c|}
\hline \multirow{2}{*}{ Days (DAP) } & \multirow{2}{*}{ Treatment } & \multicolumn{5}{|c|}{ Compost (ton ha ${ }^{-1}$ ) } \\
\hline & & 0 & 5 & 10 & 15 & 20 \\
\hline \multirow{2}{*}{42} & Without AMF & $3.40 \mathrm{a}$ & $4.22 \mathrm{ab}$ & $4.26 \mathrm{ab}$ & $4.36 \mathrm{ab}$ & $4.62 \mathrm{ab}$ \\
\hline & $\mathrm{AMF}$ & $4.17 \mathrm{a}$ & $4.26 \mathrm{ab}$ & $4.83 \mathrm{ab}$ & $5.65 \mathrm{~b}$ & $6.60 \mathrm{~b}$ \\
\hline \multicolumn{2}{|c|}{ LSD 5\% } & \multicolumn{5}{|c|}{2.43} \\
\hline
\end{tabular}

Notes : numbers followed by the same letter show non significant difference on LSD test of 5\%

Result of the regression analysis for relationship between AMF treatment and compost fertilizer by the equation of $\mathrm{M}_{0}: \mathrm{Y}=0.107 \mathrm{X}+5.68$ and $\mathrm{R}^{2}=0.984$. AMF treatment by the increasing dosage of compost from 0 to 20 ton $\mathrm{ha}^{-1}$ could increase dry weight of root by looking at trend of the inclining graphic, the equation on $\mathrm{M}_{1}: \mathrm{Y}=0.196 \mathrm{X}+6.134$ and $\mathrm{R}^{2}=0.912$ as presented in Figure 1 below.

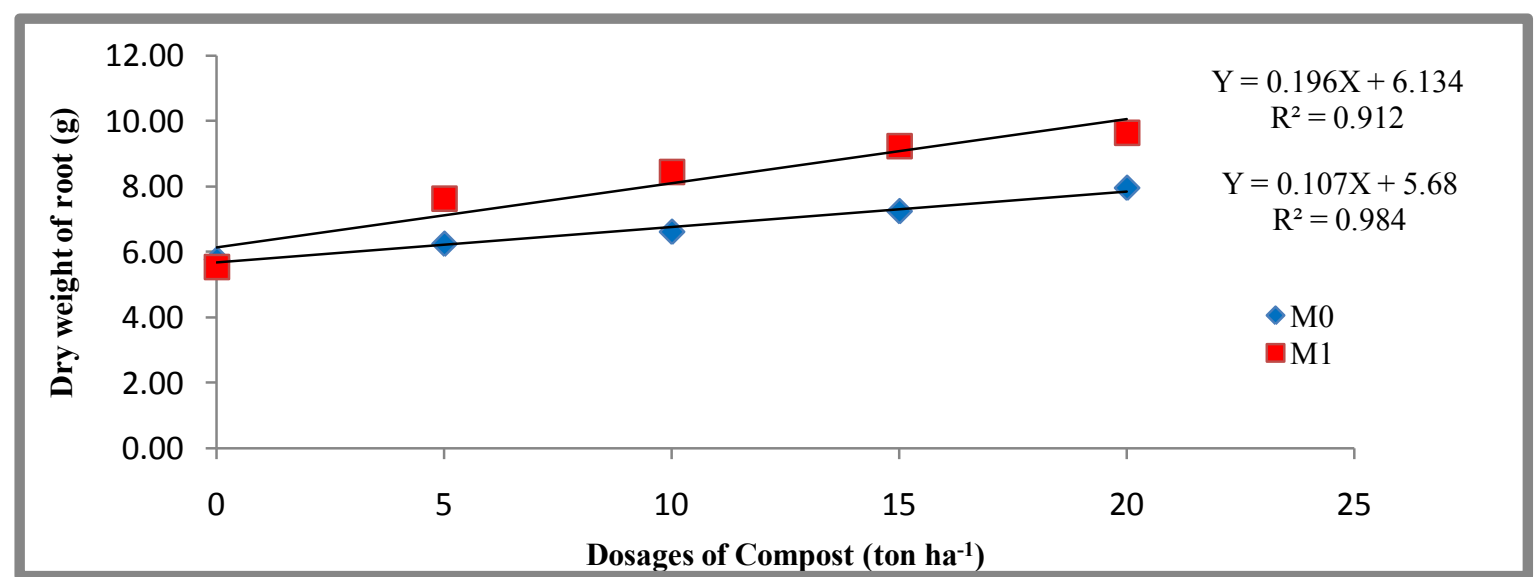

Figure 1. Relationship between dosages of compost and dry weight of root at 70 DAP on the treatment of $\mathrm{M}_{0}$ (without AMF) and $\mathrm{M}_{1}$ (AMF) 


\subsection{Weight of cob}

AMF treatment by dosage of compost 0 ton $\mathrm{ha}^{-1}$ has resulted non significant difference with the treatment without AMF by dosage of compost 20 ton ha ${ }^{-1}$. Dosages of compost 5,10 and 15 ton ha ${ }^{-1}$ could increase weight of cob and resulted non significant difference. By dosage of 15 ton ha ${ }^{-1}$, it has resulted non significant difference as dosage of 20 ton ha ${ }^{-1}$ with AMF treatment. By the application of 15 ton ha ${ }^{-1}$, it has been able to increase weight of cob, so that it could reduce the need of compost for about $25 \%$.

\subsection{Weight of 100 seeds}

AMF treatment by dosage of compost 0 ton $\mathrm{ha}^{-1}$ has resulted non significant difference as by the dosage of 10 ton ha ${ }^{-1}$ on treatment without AMF. As well as the dosage of 5 ton ha ${ }^{-1}$, the result has non significant difference as the dosage of 15 ton ha ${ }^{-1}$ without AMF. For AMF treatment by dosage of compost 5 ton $\mathrm{ha}^{-1}$ has been able to increase weight of 100 seeds in comparison with the treatment without AMF that requires compost 15 ton ha ${ }^{-1}$. By dosage of 15 ton ha ${ }^{-1}$, the result has non significant difference as the dosage of 20 ton $\mathrm{ha}^{-1}$ by AMF treatment. By dosage of 15 ton ha ${ }^{-1}$, it has been able to increase weight of 100 seeds and reduce the need of compost for about $25 \%$.

\subsection{Weight of grains}

AMF treatment by dosage of compost 5 ton ha $^{-1}$ has been able to increase weight of grains in comparison with treatment without AMF by dosage of 20 ton ha $^{-1}$. The increasing dosage of compost up to 20 ton $\mathrm{ha}^{-1}$ has still increased the yield. On AMF treatment by dosage of compost 10 ton ha ${ }^{-1}$ and 15 ton ha ${ }^{-1}$, both of them have good results in increasing weight of grains (Figure 3).

Result for analysis of variance showed interaction between AMF treatment and the compost in observation on harvest at 106 DAP, which include : weight of cob, weight of 100 seeds and weight of grains $\left(\right.$ ton $\mathrm{ha}^{-1}$ ) as presented in Table 5 below.

Table 5. Mean for weight of cob (g), weight of 100 seeds $(\mathrm{g})$ and weight of grains (ton ha ${ }^{-1}$ ) due to interaction between AMF treatment and compost at 70 DAP

\begin{tabular}{cccc}
\hline Treatment & Weight of Cob $(\mathrm{g})$ & Weight of 100 seeds $(\mathrm{g})$ & Weight of Grains $\left(\right.$ ton ha $\left.^{-1}\right)$ \\
\hline M0K0 & $103.83 \mathrm{a}$ & $22.37 \mathrm{a}$ & $5.12 \mathrm{a}$ \\
M0K1 & $127.47 \mathrm{a}$ & $22.66 \mathrm{a}$ & $5.49 \mathrm{a}$ \\
M0K2 & $125.53 \mathrm{ab}$ & $22.99 \mathrm{ab}$ & $5.62 \mathrm{a}$ \\
M0K3 & $137.94 \mathrm{ab}$ & $24.01 \mathrm{bc}$ & $6.06 \mathrm{~b}$ \\
M0K4 & $155.06 \mathrm{ab}$ & $24.63 \mathrm{c}$ & $5.54 \mathrm{a}$ \\
M1K0 & $130.81 \mathrm{ab}$ & $23.34 \mathrm{ab}$ & $6.69 \mathrm{c}$ \\
M1K1 & $181.47 \mathrm{bc}$ & $23.98 \mathrm{bc}$ & $7.78 \mathrm{~d}$ \\
M1K2 & $196.94 \mathrm{c}$ & $24.83 \mathrm{~cd}$ & $8.08 \mathrm{~d}$ \\
M1K3 & $233.69 \mathrm{~cd}$ & $25.68 \mathrm{de}$ & $8.63 \mathrm{e}$ \\
M1K4 & $277.92 \mathrm{~d}$ & $26.009 \mathrm{e}$ & 0.37 \\
\hline LSD 5\% & 66.87 & 1.05 &
\end{tabular}

Notes : numbers followed by the same letter show non significant difference on LSD test of 5\%

Result of the regression analysis on treatment without $\mathrm{AMF}$ by the equation : $\mathrm{Y}=0.042 \mathrm{X}+5.18$ with $\mathrm{R}^{2}=0.960$. AMF treatment by increasing dosage of compost from 0 to 20 ton ha ${ }^{-1}$ has been able to increase weight of grains for about three times in comparison with the treatment without AMF, by the equation $\mathrm{Y}=$ $0.146 \mathrm{X}+5.938$ with $\mathrm{R}^{2}=0.923$ as presented in Figure 2 below .

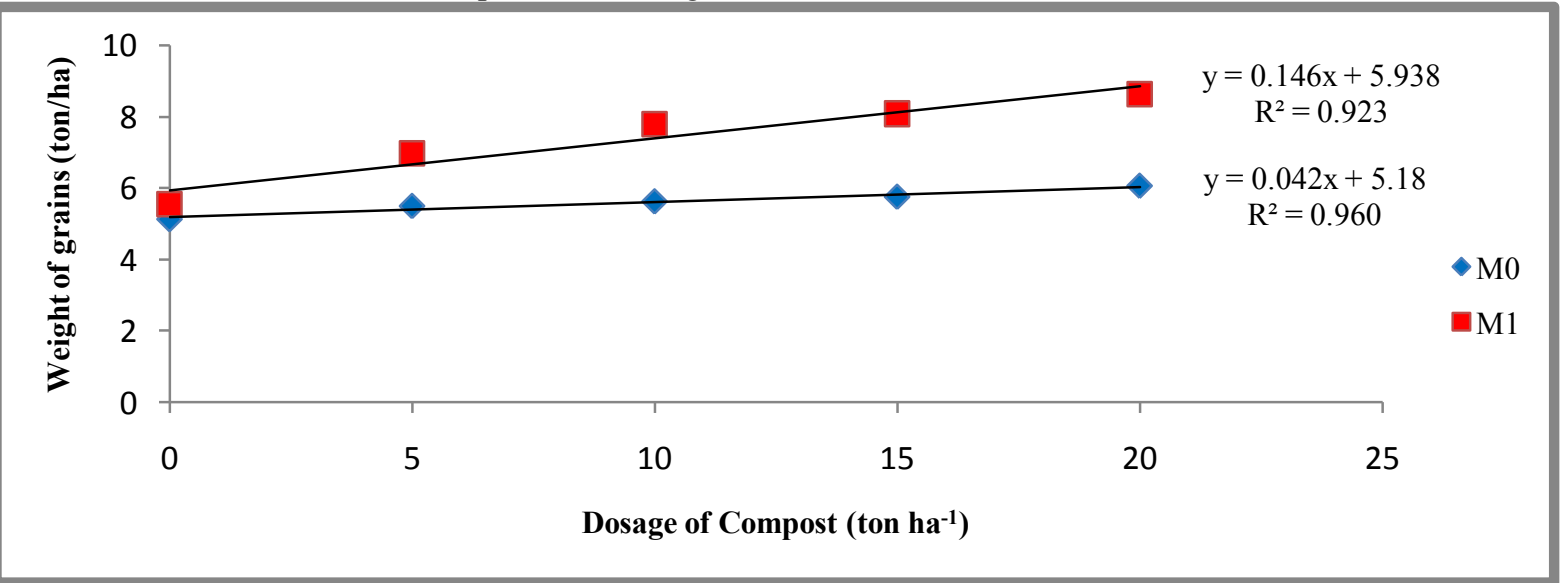

Figure 2 : Relationship between dosage of compost (ton ha $\left.{ }^{-1}\right)$ and weight of grains (ton ha $\left.{ }^{-1}\right)$ on treatment M0 (without AMF) and M1(AMF) 


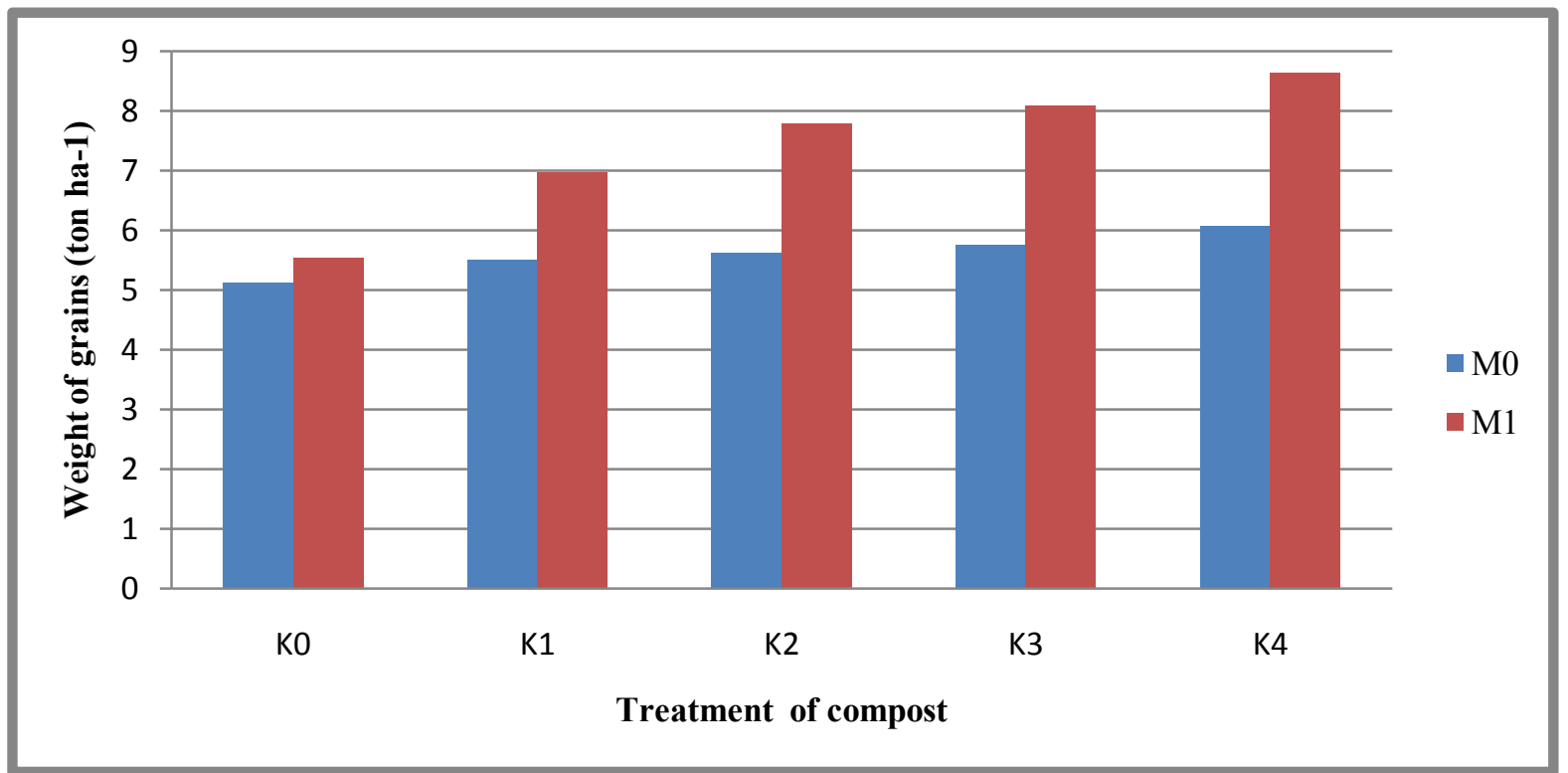

Figure 3 : Relationship between treatment of compost and weight of grains (ton ha $^{-1}$ ) on treatment M0 and M1

AMF and compost have significant effect on growth of plants, interactions occur in all variables of growth as observed on days of observation. AMF could provide positive effect that support growth of the plant because it could increase absorbability of water and nutrients, increase tolerance to nutrient deficiency in the soil that contain low organic materials and increase viability of the plant during early growth (Moelyohadi et al., 2012)[7]. AMF development is also affected by type of host and metabolism process that produces carbon from exudates of the plant's roots, which can be utilized for AMF development (Rungkat, 2009) [8]. Some positive effects, as a result of symbiosis with AMF, include: increasing absorbability of water and nutrients, particularly $\mathrm{N}, \mathrm{P}$, and $\mathrm{K}$, resistance to pathogenic infection on root, tolerant to nutrient deficiency, increasing photosynthetic rate and increasing survivability during early growth (Widiastuti et al., 2003) [9].

Increasing yields for each dosage of compost with AMF are as follow: dosage 0 ton $\mathrm{ha}^{-1}$ is $8.20 \%, 5$ ton $\mathrm{ha}^{-1}$ is $26.78 \%, 10$ ton $\mathrm{ha}^{-1}$ is $38.43 \%, 15$ ton $\mathrm{ha}^{-1}$ is $40.52 \%$ and 20 ton ha $\mathrm{h}^{-1}$ is $42.41 \%$. The increasing grain yield due to AMF and the organic acids would increase $\mathrm{P}$ availability in the soil and along with hypha AMF could increase the range of $\mathrm{P}$ adsorption per area unit. Increasing $\mathrm{P}$ availability in the soil and increasing adsorption would increase the yield because $\mathrm{P}$ is required in establishing and maturing the seeds during generative phase on maize. The increasing yield of corn's grains by AMF inoculation through external hypha has been able to extend the root's adsorption area, so that the plant would obtain sufficient nutrient supplies to increase the yield (De la Cruz, 1991) [10].

\section{Conclusion}

AMF treatment and compost have significant effect on diverse parameters and days of observation. On parameter of growth, AMF treatment and compost by dosage of 10 ton $\mathrm{ha}^{-1}$ could increase leaf area, dry weight of root, dry weight of shoot and dry weight of cob, as well as reduce the need of compost for about $50 \%$. On parameter of yield, AMF and compost 15 ton $^{-1}$ have been able to increase weight of ear and weight of 100 seeds, as well as reduce the need of compost $25 \%$, meanwhile for weight of grains, the increasing dosage 20 ton $\mathrm{ha}^{-1}$ has still increased the yield. The use of AMF by dosages of compost 10 ton $\mathrm{ha}^{-1}$ and 15 ton ha ${ }^{-1}$ show that both of them are good in increasing weight of grains on maize.

\section{References}

[1]. Ministry of Agriculture, Prospect and Developmental Direction of Agribusiness on Maize, Ministry of Agricultural Research and Development, Jakarta, 2014.

[2]. Handayanto, E and K. Hairiah, Soil biology as basic in managing healthy soil, Pustaka Adipura, Yogyakarta, 2007, 97-155.

[3]. Atmojo, S. W., Environmentally safe-land resources management, Sebelas Maret University Press, Surakarta, 2010.

[4]. Mosse, B., Vesicular arbuscular mycorrhiza Research for Tropical Agriculture, Research Bulletin 194, University of Hawaii, 1981, $82 \mathrm{p}$.

[5]. Blal, B., C. Morel, V. Gianinazzi, Influence of vesicular arbuscular mycorrhizae on phospate fertilizer efficiency in two tropical acid soils planted with micropropagated oil palm (Elaeis guineensis, Jacq), J.Bio Fertil. Soils. 9, 1990, 43-48.

[6]. Jan, B., M. Sharif, F. Khan and J. Bakht,, Effect of arbuscular mycorrhiza fungal inoculation with compost on yield and P uptake of wheat in alkaline calcareous soil, American J. of Plant Sci.5, 2014, 1-11.

[7]. Moelyohadi, Y., M.U. Harun, Munandar, R. Hayati dan N. Gofar, Utilization of diverse types of biological fertilizers in breeding nutrient-efficient corn in marginal dry land, J. Suboptimal Land. 1, 2012, 31-39. 
The Effect of Arbuscular Mycorrhizae Fungi (AMF) Glomus sp. and Compost on Growth and .....

[8]. Rungkat, J.A., The role of vesicular arbuscular mycorrhizae in increasing growth and production of the crops, J. Formas. 2(4), 2009, $270-276$.

[9]. Widiastuti, H., E. Guhardja, N. Sukarno, L.K. Darusman, D.H. Goenadi and S. Smith, The root architecture of the oil palm's seeds inoculated with some arbuscular mychorrizae, Menara Perkebunan. 7(1), 2003, 28-43.

[10]. De la Cruz, R.E., Final report of the consultant on mycorrhizal program development in the IUC Biotechnology Center, Inter University Center, IPB, 1991.

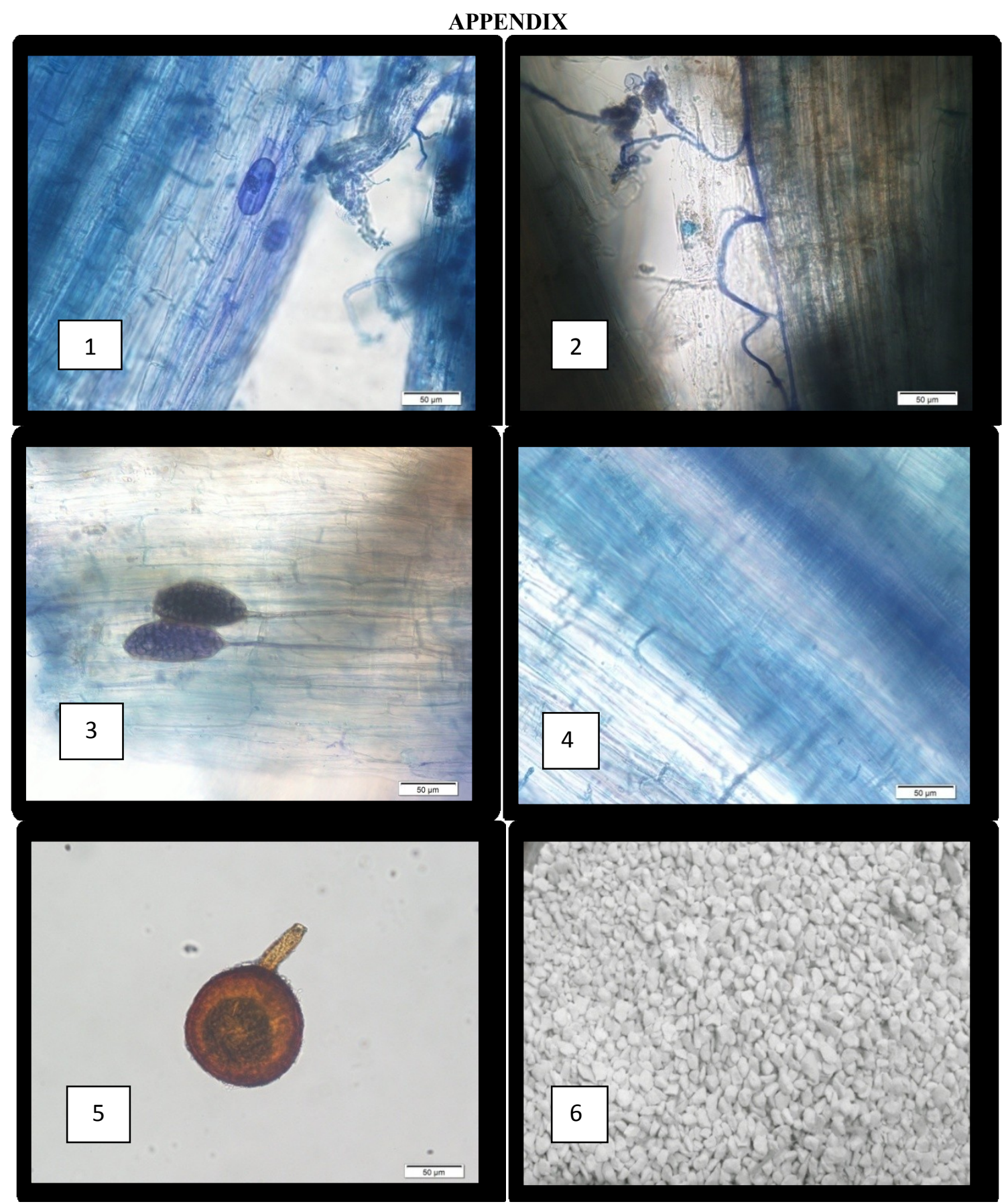

Notes :

Fig. 1-3 : Arbuscular Mycorrhizae Fungi infection in maize roots

Fig. 4 : Maize roots uninfected of Arbuscular Mycorrhizae Fungi

Fig. 5 : Spores of Arbuscular Mycorrhizae Fungi Glomus sp.

Fig. 6 : Arbuscular Mycorrhizae Fungi using zeolith medium 